\title{
Perancangan Aplikasi Peristiwa Kriminal Dengan Pendekatan Contextual Design
}

\author{
Yusrizal, Ramzi Adriman, Nasaruddin Syafie \\ Jurusan Teknik Elektro dan Teknik Komputer, Universitas Syiah Kuala Jl. Tgk. Syech Abdul Rauf No. 7 Darussalam, Banda Aceh 23111
}

\section{KATA KUNCI \\ Kriminal, kebutuhan user, contextual design}

\section{CORRESPONDENCE}

Phone: +6282160146090

E-mail: yoserizal@mhs.unsyiah.ac.id

\section{PENDAHULUAN}

Pemetaan lokasi kriminal sangat berguna bagi pihak kepolisian dan masyarakat. Dengan adanya pemetaan yang menampilkan tingkat kerawanan kriminal pada suatu wilayah, pimpinan kepolisian di wilayah tersebut akan terbantu dalam proses pengambilan keputusan [1]. Keputusan yang diambil dalam rangka meminimalisir kejadian kriminal antara lain seperti melakukan pencegahan, mulai dari menugaskan personel untuk melakukan penyuluhan, hingga menempatkan personel dalam melakukan pemantauan pada suatu wilayah berdasarkan tingkat kerawanan kriminalnya. Pada proses kerja selama ini, Kepolisian Republik Indonesia (POLRI) masih menggunakan pemetaan dalam bentuk konvensional seperti gambar peta pada kertas yang ditempelkan pada kantor kepolisian [2].

Hingga saat ini, jumlah personel kepolisian pada suatu wilayah belum mencapai tahap ideal, yaitu 1 (satu) orang polisi untuk 100 orang masyarakat, sehingga pengawasan yang dilakukan akan menjadi kurang efektif. Selain itu, penempatan personel yang tidak tepat sasaran juga dapat mempengaruhi efisiensi kinerja pihak kepolisian disebabkan banyak sumber daya (resource) yang ditempatkan bukan pada daerah yang rawan mengalami kejadian criminal. Untuk menghindari terjadinya hal-hal tersebut, maka pihak kepolisian perlu melakukan analisa dan evaluasi wilayah yang rawan mengalami kejadian criminal [3].

Meskipun demikian, pihak kepolisian masih menggunakan data dan informasi yang disimpan pada arsip serta peta konvensional. Seperti yang diketahui, penggunaan peta konvensional pada kantor kepolisian dapat menimbulkan beberapa masalah dikarenakan memiliki kelemahan. Masalah yang muncul antara lain seperti terbatasnya informasi kejadian kriminal pada suatu wilayah yang ditampilkan karena peta tersebut memiliki ruang yang terbatas. 
Selanjutnya peta konvensional juga tidak mampu menampilkan gambar bangunan seperti pada citra satelit sehingga kurang akurat. Selain itu, tidak adanya umpan balik (feedback) dari tingkat kerawanan kriminal pada suatu wilayah, akan memperlama proses pengambilan keputusan oleh pimpinan kepolisian. Bagaimanapun juga, tingkat ketahanan yang dimiliki oleh peta konvensional sangatlah kurang disebabkan bahannya terbuat dari kertas sehingga rawan rusak karena robek atau basah. Bahkan, sulitnya proses diseminasi informasi dari pihak kepolisian kepada masyarakat dapat mengurangi kesadaran masyarakat dalam berpartisipasi untuk menjaga keamanan di lingkungannya.

Berdasarkan permasalahan yang terjadi, telah dilakukan penelitian [4-17] tentang aplikasi pemetaan criminal, akan tetapi aplikasi tersebut masih memiliki kekurangan seperti belum menggunakan pendekatan atau metode yang dikenal dalam proses perancangan perangkat lunak. Selain itu, proses perancangan tidak melibatkan user sehingga tidak diketahui kesesuaian antara aplikasi dengan kebutuhan user sehingga dibutuhkan penelitian lanjutan untuk merancang aplikasi yang berdasarkan pada kebutuhan user.

Dari beberapa permasalahan yang ditemukan pada peta kriminal yang terdapat di kantor kepolisian, maka ditawarkan solusi dalam proses perancangan menggunakan pendekatan contextual design. Contextual Design merupakan pendekatan yang digunakan untuk mendapatkan kebutuhan user melalui studi lapangan, rasionalisasi alur kerja, serta mendesain antarmuka manusia dan computer sehingga menghasilkan desain yang lengkap pada sistem, mulai dari back end, hingga front end [18].

Sementara itu, dalam proses perancangan aplikasi, terdapat 6 (enam) langkah yang dilakukan. Pada langkah pertama dilakukan wawancara kontekstual untuk mengetahui proses pemetaan criminal selama ini. Kemudian dilakukan interpretasi dari hasil wawancara yang telah dilakukan. Setelah itu dilakukan konsolidasi data untuk menghilangkan redundansi dari seluruh user. Lalu dilakukan visioning untuk mendapatkan gambaran proses kerja baru. Selanjutnya dibuat storyboarding untuk mengetahui detail proses user dalam menggunakan aplikasi. Kemudian dibuat user environment design untuk mendapatkan gambaran proses yang berjalan pada aplikasi. Pada langkah terakhir dilakukan prototyping untuk mendapatkan desain antarmuka pengguna (user interface) dari aplikasi [19].

Pada proses kerja baru ini, user akan menambahkan profil kejadian kriminal seperti nama kasus, pasal yang dilanggar, nama pelaku, alamat pelaku dan informasi lainnya pada lokasi Tempat Kejadian Perkara (TKP). Selain itu, aplikasi peristiwa kriminal ini dilengkapi dengan beberapa fitur seperti lokasi kantor polisi terdekat sehingga dapat memudahkan masyarakat dalam melaporkan kasus, pengaduan masyarakat, Daftar Pencarian Orang (DPO), bahkan tren kriminal. Selain itu, masyarakat juga akan diberikan tips-tips dalam menanggulangi kejadian kriminal. Semua proses tersebut dilakukan dengan menggunakan aplikasi mobile sehingga akan mempermudah kerja user tanpa perlu mengakses komputer.

Dengan adanya perancangan aplikasi peristiwa kriminal menggunakan pendekatan Contextual Design, maka diharapkan

152 Yusrizal dapat memaksimalkan pengalaman user dalam menggunakan aplikasi sehingga menjadi lebih menyenangkan, menangkap kebutuhan user dengan benar, serta mendapatkan keluaran yang sesuai dengan kebutuhan mereka. Hal ini bertujuan untuk membantu pihak kepolisian sehingga dapat mempermudah kinerja mereka dalam proses mengelola data criminal.

\section{METODE PENELITIAN}

Terdapat beberapa tahapan yang harus dilalui dalam menangkap kebutuhan user menggunakan pendekatan Contextual Design. Tahapan dari perancangan aplikasi menggunakan pendekatan Contextual Design dapat dilihat pada gambar 1:

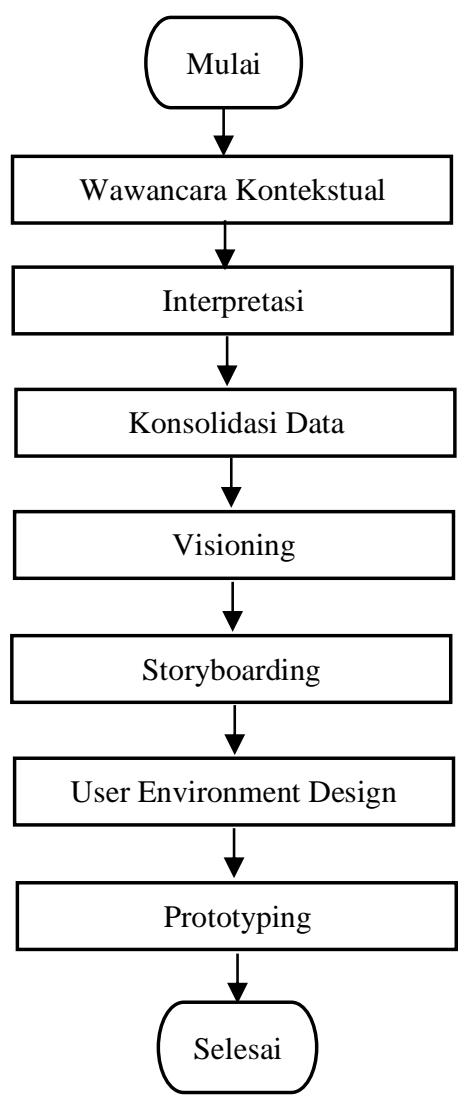

Gambar 1. Alur Penelitian

Dari gambar 1 dapat dilihat bahwa ada tahap pertama, dilakukan identifikasi kelompok user untuk menentukan user yang akan diwawancarai dan dibagi menjadi user polisi dan user masyarakat. Pengelompokan user ini dilakukan karena masingmasing user memiliki kebutuhan yang berbeda pada aplikasi.

Setelah diketahui kelompok user, tahap selanjutnya akan dilakukan wawancara kontekstual dengan user. Disini user ditanyai berbagai pertanyaan yang telah disusun dan mencakup What, When, Who, Where, Why dan How (5W1H). Saat wawancara berlangsung, seluruh pertanyaan dan jawaban akan direkam agar mudah untuk dituliskan kembali setelah wawancara selesai. Kemudian dilakukan interpretasi dari hasil wawancara dengan cara menuliskan jawaban user pada sticky notes dan ditempelkan pada dinding secara berkelompok berdasarkan topik pertanyaan.

Setelah jawaban hasil wawancara ditempelkan pada dinding, maka jawaban tersebut akan dianalisa sehingga didapatkan permasalahan secara rinci. Selanjutnya dilakukan visioning yang 
merupakan proses dari brainstorming untuk mendapatkan solusi dari permasalahan yang terjadi. Berdasarkan solusi tersebut kemudian dilakukan storyboarding yang memuat cerita user saat menggunakan sistem yang baru. Lalu dibuat user environment desain untuk mendapatkan lingkungan kerja user dari berbagai bagian sistem.

Kemudian dilakukan proses prototyping yang memindahkan sketsa prototype dalam bentuk prototype sehingga didapatkan rancangan dari aplikasi. Selanjutnya dibuat Entity Relationship Diagram (ERD) yang memuat entitas dan hubungannya dalam sistem.

\section{HASIL DAN PEMBAHASAN}

\section{Sistem Pemetaan Konvensional}

Pada sistem pemetaan kriminal selama ini, terdapat 2 (dua) kelompok user yang membutuhkan pemetaan criminal yaitu user dari polisi dan user dari masyarakat. User polisi merupakan user yang membuat pemetaan kriminal, yang dalam melakukan tugasnya dengan cara melakukan pencegahan dan penindakan terhadap pelaku kriminal. Oleh karena itu, maka user ini bertugas menerima laporan dari masyarakat, memproses kasus kriminal beserta pelakunya, membuat pemetaan kriminal dan membuat keputusan.

Sementara itu, user masyarakat merupakan user pengguna yang hanya membutuhkan informasi tentang keadaan di wilayah sekitarnya sehingga dapat melakukan pencegahan terhadap kejadian kriminal. Selain itu, user masyarakat juga perlu melaporkan kejadian kriminal ke user polisi agar mendapatkan perlindungan dari mereka dan agar memudahkan user polisi dalam memproses suatu kasus.
Berikut ini ditampilkan bagan alir langkah kerja yang dilakukan oleh user dalam melakukan pemetaan kriminal secara umum pada gambar 2:

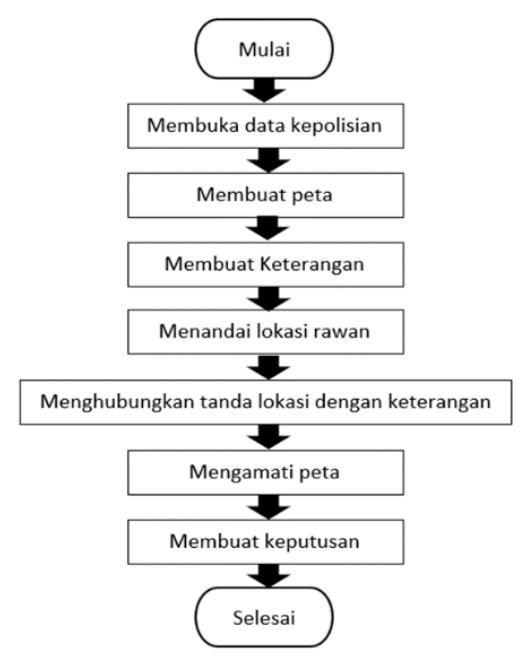

Gambar 2. Bagan alir proses pemetaan kriminal secara umum

Pada gambar 2 terlihat bahwa pada tahap awal sistem kerja yang lama, user akan membuka data kepolisian yang berasal baik dari laporan personil di lapangan, laporan intelijen, dan laporan masyarakat. Selanjutnya user akan membuat peta dengan cara konvensional seperti menyiapkan kertas dan berbagai peralatan lainnya yang dapat digunakan untuk membuat dan menempelkan peta. Kemudian user akan membuat keterangan dari setiap lokasi dengan menampilkan kasus dan jumlah kejadian beserta petugas yang melakukan pemantauan di lapangan.

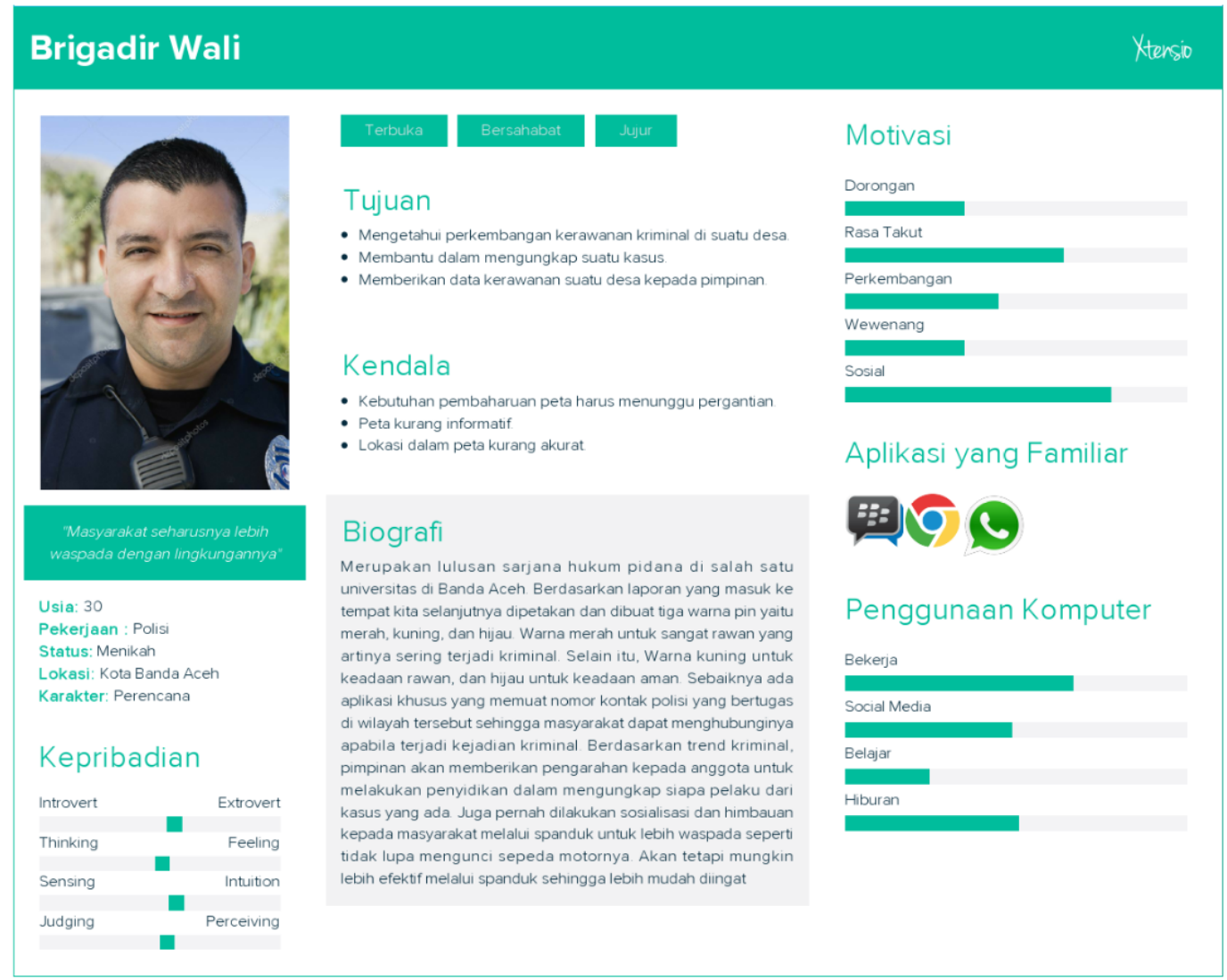

Gambar 3. User Persona dari pemetaan kriminal 
Setelah peta dibuat, selanjutnya user akan menandai lokasi yang rawan pada peta sehingga dapat diketahui lokasi mana saja yang rawan kriminal. Selanjutnya user akan menghubungkan lokasi yang rawan kriminal tadi dengan keterangan yang telah dibuat. Lalu user akan mengamati peta beserta keterangannya yang telah dibuat dan akan membuat keputusan baik berupa pencegahan maupun penindakan dengan melibatkan unit lainnya. Apabila telah mencapai masa 6 bulan, maka user akan memperbaharui peta kembali dengan menyimpan peta lama dan kemudian membuat peta baru.

\section{Perancangan Contextual Design}

Dalam perancangan aplikasi pemetaan kriminal ini, untuk proses awalnya dilakukan dengan menangkap kebutuhan user (user requirement) melalui pendekatan Contextual Design. Pendekatan ini memiliki beberapa tahap seperti wawancara kontekstual, interpretasi, konsolidasi data, visioning, storyboarding, user environment design, dan prototyping. Pada sistem yang baru, proses pemetaan kriminal akan dilakukan melalui aplikasi mobile yang akan membantu user dalam pengelolaan pemetaan kriminal.

\section{Wawancara Kontekstual}

Pada tahap pertama dari proses perancangan, dilakukan proses wawancara langsung dengan user. Adapun proses wawancara ini berguna untuk mengetahui bagaimana kerja user polisi dan masyarakat dalam memenuhi kebutuhannya terhadap informasi kriminal. Sebelum dilakukan wawancara, terlebih dahulu dibuat daftar pertanyaan yang akan ditanyakan ke user. Daftar pertanyaan tersebut memiliki perbedaan antara user polisi dengan daftar wawancara user masyarakat. Meskipun berbeda, akan tetapi hal yang perlu ditangkap dari user polisi dan user masyarakat pada intinya mencakup alasan dasar, motivasi, dan opini. Output dari wawancara kontekstual adalah User Persona sebagaimana diperlihatkan pada Gambar 3.

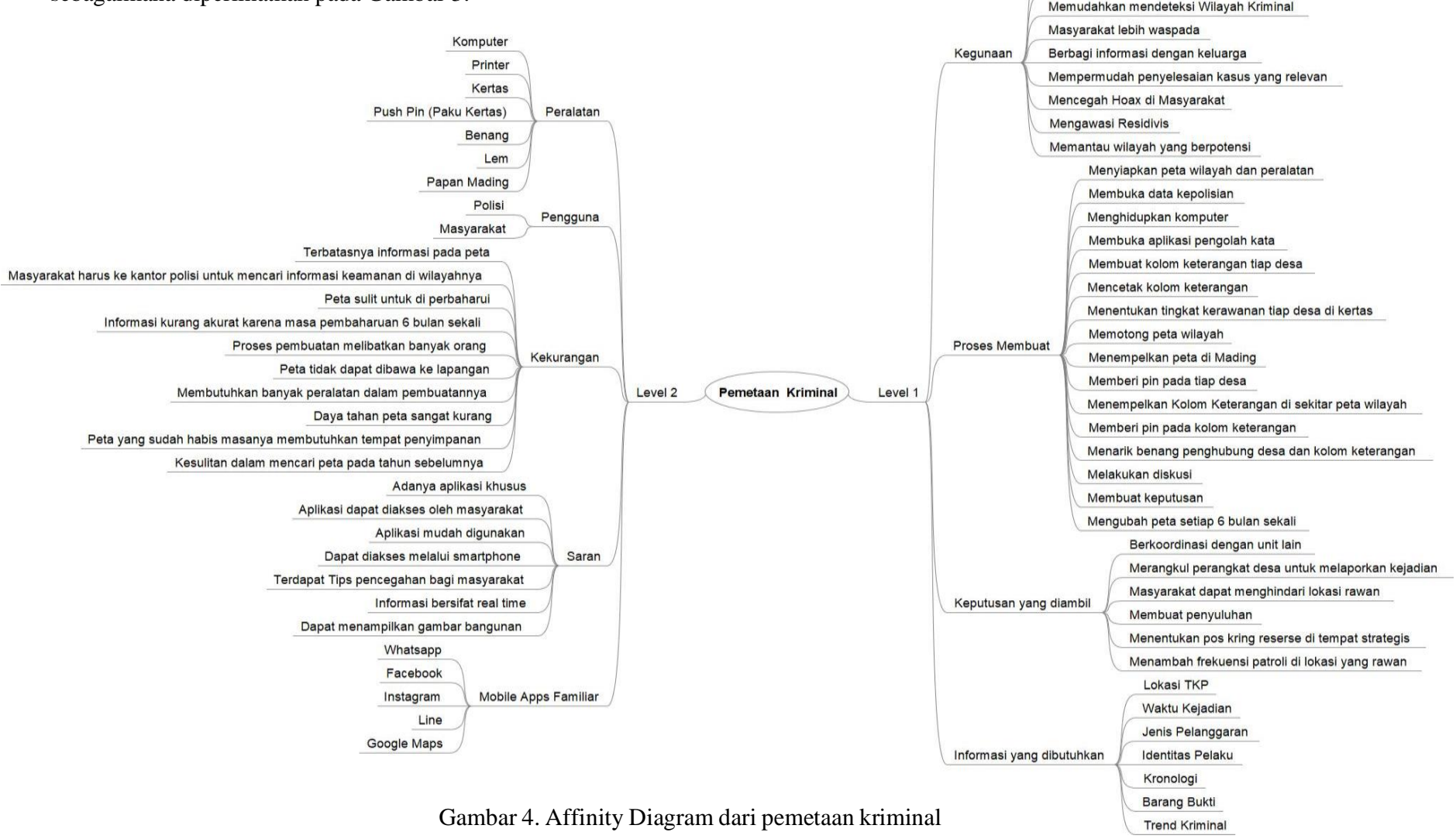

Setelah hasil wawancara dicatat pada Microsoft Word, selanjutnya dibuat persona dari setiap user yang telah diwawancarai. Adapun persona yang dibuat meliputi user polisi dan user masyarakat dan dirahasiakan identitasnya dengan cara mengganti nama dan foto user yang telah diwawancarai. Persona diperlukan untuk membantu dalam perancangan sehingga menjadi lebih fokus dengan karakter dan dapat ditampilkan kebutuhan mereka pada sistem.

\section{Interpretasi}

Berdasarkan jawaban dari masing-masing user yang pada User Persona, maka langkah selanjutnya adalah menginterpretasikan jawaban tersebut. Pada awalnya, dibuat topik terlebih dahulu seperti kegunaan pemetaan kriminal, proses membuatnya, keputusan apa saja yang dapat diambil dari pemetaan kriminal, informasi apa saja yang dibutuhkan dalam pemetaan kriminal, peralatan yang dibutuhkan, pihak yang terlibat, kekurangan, dan saran. Kemudian setiap jawaban user dicatat pada selembar kertas sticky notes dan ditempelkan di dinding berdasarkan topik yang sesuai. Setelah itu dilakukan seleksi terhadap jawaban yang akan ditempelkan dengan cara melewatkan jawaban yang sama pada satu topik untuk menghindari terjadinya pengulangan kata yang memiliki makna yang sama (redundancy) 


\section{Konsolidasi Data}

Setelah melakukan interpretasi, maka selanjutnya dibuat model kerja dari berbagai aspek yang berbeda dalam bentuk mind map menggunakan aplikasi FreeMind. Hal ini bertujuan untuk mendapatkan proses kerja, fitur dan inovasi dari pemetaan kriminal yang disajikan dalam bentuk Affinity Diagram. Adapun topik yang terdapat pada diagram ini adalah kegunaan, proses membuat, keputusan yang diambil, informasi yang dibutuhkan, peralatan, pengguna, kekurangan, saran, dan mobile apps familiar. Affinity Diagram dari pemetaan kriminal ditunjukkan seperti pada Gambar 4.

\section{Visioning}

Pada tahap ini, data user yang telah dikonsolidasi selanjutnya dipikirkan bagaimana meningkatkan kerja user dengan menggunakan teknologi untuk mengubah proses pemetaan kriminal selama ini. Sementara itu, visi menangkap cerita tentang bagaimana user akan menggunakan pemetaan kriminal dengan proses kerja baru yang diusulkan. Visi yang dikembangkan meliputi sistem, proses kerjanya, dan dukungan untuk membuat pemetaan kriminal menjadi lebih baik. Hal ini diperlukan untuk memberikan solusi dan memastikan keterhubungan sistem yang digunakan.

Dari permasalahan yang selama ini ditemukan pada sistem pemetaan kriminal, maka dibutuhkan adanya suatu aplikasi yang dapat membuat pemetaan secara digital dan dapat membagikannya kepada user yang lain. Oleh karena itu, pemetaan kriminal melalui aplikasi mobile merupakan solusi dari permasalahan tersebut. Hal ini disebabkan akan kemudahan yang akan didapatkan oleh user baik dalam proses pembuatan, pengambilan keputusan, hingga proses desiminasi informasi kepada user yang lain.

Terdapat 2 (dua) user yang berhubungan dengan sistem pemetaan kriminal, yaitu user polisi dan user masyarakat. User polisi dapat melihat lokasi kerawanan desa berdasarkan tingkatannya tanpa perlu menghitung kembali jumlah kejadian di sekitar lokasi. Kemudian polisi juga akan dipermudah dalam melakukan pemantauan terhadap residivis dan memeriksa saksi di lapangan dengan menunjukkan identitas pelaku residivis. Selain itu, proses pengambilan keputusan oleh pimpinan polisi menjadi lebih mudah karena disajikan secara langsung oleh aplikasi.

Sementara pada user masyarakat, informasi yang dibagikan oleh polisi melalui aplikasi akan dapat dilihat secara langsung dan dapat melakukan pencegahan serta meningkatkan kewaspadaan terhadap ancaman aksi kriminal pada dirinya dan keluarganya. Selanjutnya user masyarakat juga dapat membuat pengaduan kepada polisi dan membuat panggilan secara cepat ke kantor polisi terdekat. Selain itu user masyarakat juga dapat membagikan informasi pada aplikasi kepada temannya melalui aplikasi berkirim pesan atau media social lainnya.

Meskipun informasi yang dibagikan oleh user polisi dapat dilihat oleh user masyarakat, akan tetapi user masyarakat hanya mendapatkan informasi terbatas seputar kerawanan di lingkungannya dan cara pencegahannya saja. Adapun akses yang dibatasi tersebut disebabkan oleh pembagian hak akses dimana user polisi menjadi Admin dan user masyarakat hanya menjadi user biasa sehingga tidak dapat menggunakan fitur seperti edit kejadian dan lain sebagainya. Untuk menghindari adanya informasi bohong (hoaks), maka user masyarakat harus mendaftar terlebih dahulu untuk menggunakan aplikasi sehingga aplikasi hanya dapat digunakan oleh user yang mendaftar. Adapun proses kerja baru dapat dilihat pada Gambar 5:

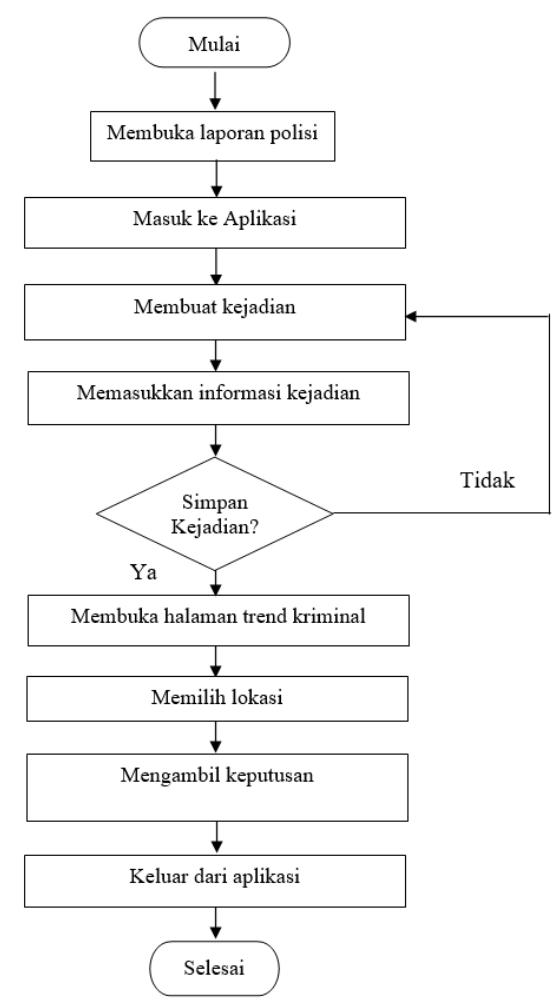

Gambar 5. proses kerja baru user

\section{Storyboarding}

Tahap selanjutnya setelah melakukan visioning dan mendapatkan proses kerja user yang baru adalah mengembangkannya dalam bentuk storyboarding. Suatu storyboard mengilustrasikan urutan linear yang tersusun bersama untuk menggambarkan suatu cerita dalam penggunaan aplikasi pemetaan kriminal baik oleh user polisi maupun user masyarakat. Selain itu, storyboard juga membentuk perjalanan user dan karakter (persona) dalam menggunakan aplikasi pemetaan kriminal. Dalam proses membuatnya, suatu scenario memuat karakter dari persona, skenario (scene), alur cerita (plot), dan narasi. Adapun storyboard dari user polisi ditunjukkan pada Gambar 6:

Nama Project, Pemetaan Kriminal App oleh Polisi
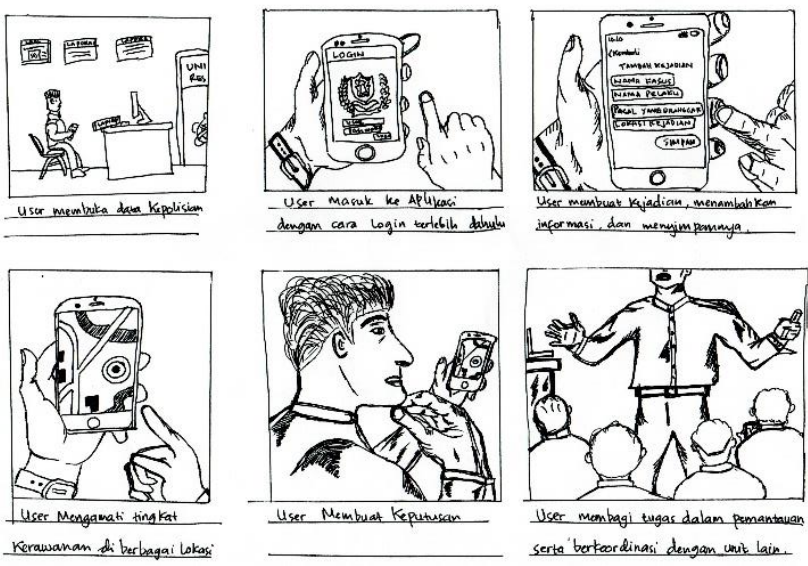

Gambar 6. proses kerja baru user polisi 
Dari Gambar 6 diatas dapat diketahui bahwa proses awal user polisi menggunakan aplikasi adalah membuka data kepolisian. Selanjutnya user masuk ke aplikasi dengan cara login terlebih dahulu dengan username dan password yang dimiliki. Kemudian user membuat kejadian pada aplikasi dengan menambahkan informasi yang ada pada data kepolisian dan menyimpannya. Setelah itu user melakukan analisa dan evaluasi tentang kerawanan di suatu wilayah dengan membuka halaman trend pada aplikasi. Pada tahap berikutnya, user membuat keputusan dan selanjutnya membuat keputusan. Sedangkan storyboard user masyarakat dapat dilihat pada Gambar 7:

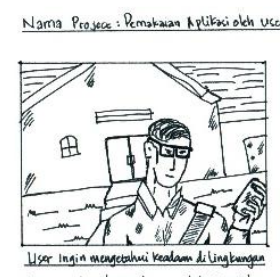

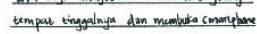

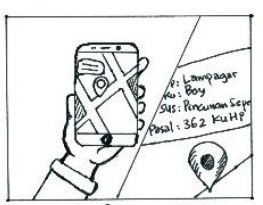

User melinat kejadian di selitar.

blain
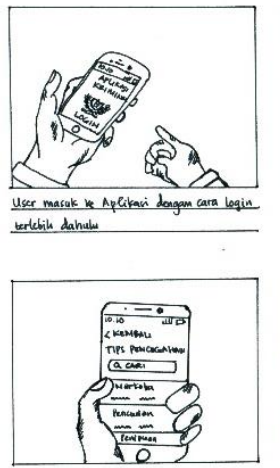

User mencari tips penagaghan dari polsisi

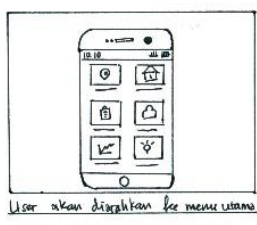

User akan disahkan be meme utam

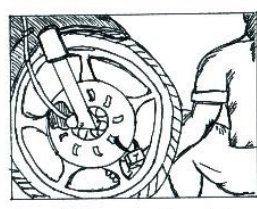

Uarer melatuken pencegahan dalam. lingtungannua maing - maring
Gambar 7. proses kerja baru user masyarakat
Pada skenario pemakaian aplikasi oleh user masyarakat seperti pada Gambar 7, proses dimulai dengan user yang membuka smartphone dan masuk ke aplikasi dengan melakukan login sesuai username dan password yang dimiliki. Selanjutnya user diarahkan ke menu utama dan user mencari tahu keadaan di sekitarnya sesuai dengan kejadian yang ada pada aplikasi. Kemudian user mencari tips pencegahan yang terdapat pada aplikasi dan melakukan pencegahan dalam lingkungannya.

\section{User Environment Design (UED)}

Setelah diketahui scenario penggunaan aplikasi oleh masingmasing user, selanjutnya akan dikembangkan rancangan dari lingkungan kerja user pada berbagai tugas yang dilakukan oleh mereka dalam aplikasi pemetaan kriminal. Pada tahap ini, akan dibuat struktur dasar dari aplikasi pemetaan kriminal yang diungkapkan oleh gambar antarmuka pengguna dan menjadi pondasi dari sistem yang baru. Sementara itu, tahap ini akan menghasilkan suatu diagram yang menunjukkan setiap bagian dari aplikasi kriminal dan berbagai antarmuka aplikasi lainnya. Adapun User Environment Design (UED) dari aplikasi dapat dilihat Gambar 8.

\section{Prototyping}

Pada tahap terakhir dari pendekatan Contextual Design, dibuat prototype dari aplikasi. Setelah itu dikembangkan paper prototype untuk diuji kembali pada user polisi dan user masyarakat sehingga dapat ditemukan permasalahan yang mungkin terjadi pada aplikasi. Kemudian digambar contoh aplikasi pemetaan kriminal pada selembar kertas dengan tangan yang mewakili kotak dialog, tombol, menu dan elemen antarmuka lainnya yang digunakan oleh user. Lalu prototype tersebut akan diuji oleh user secara langsung dan permasalahan yang didapatkan akan diubah pada desain dari aplikasi sehingga sesuai dengan kebutuhan user polisi dan masyarakat.

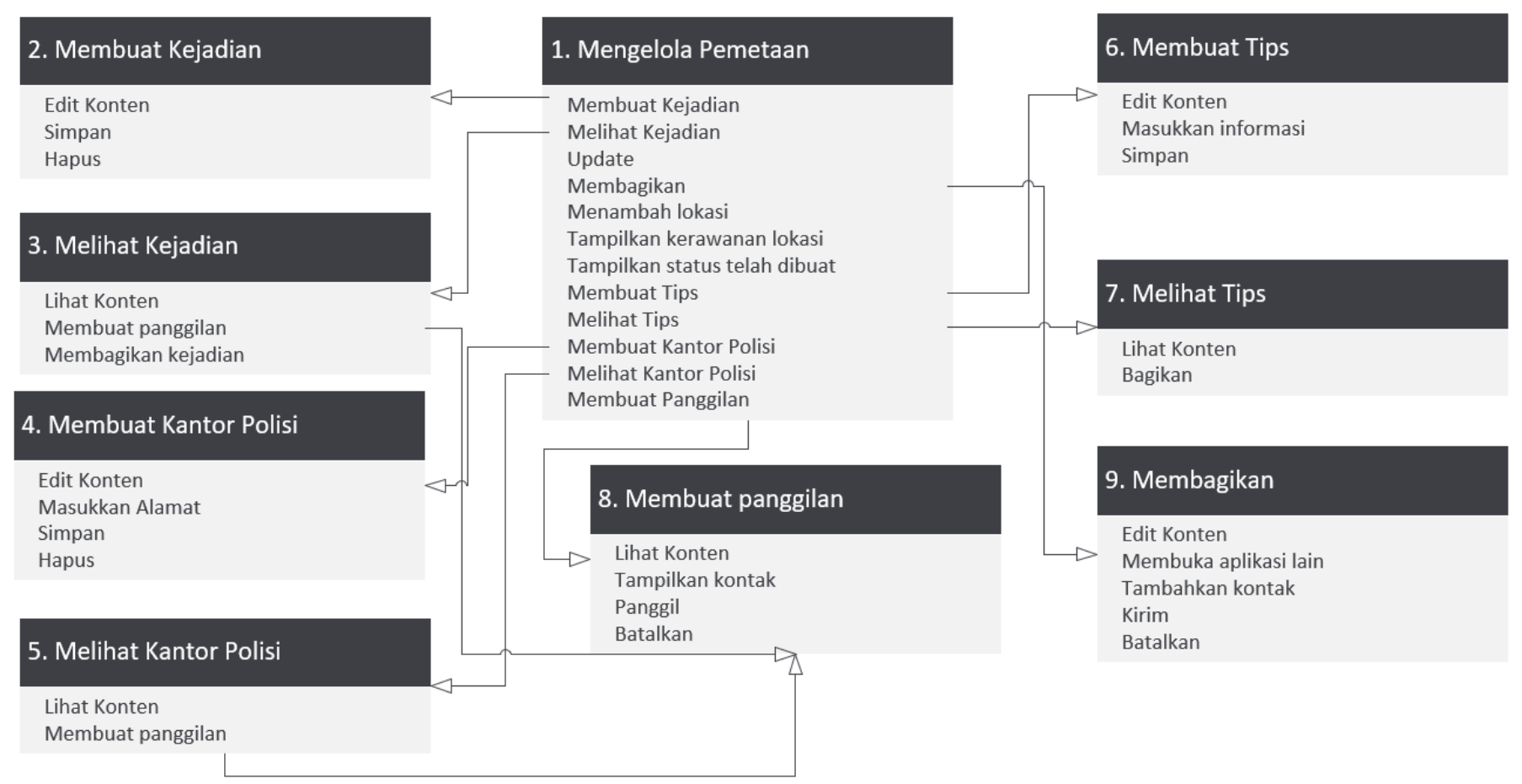

Gambar 8. User Environment Design (UED) dari aplikasi 
Adapun tampilan paper prototype seperti ditunjukkan pada Gambar 9 sampai dengan Gambar 17:
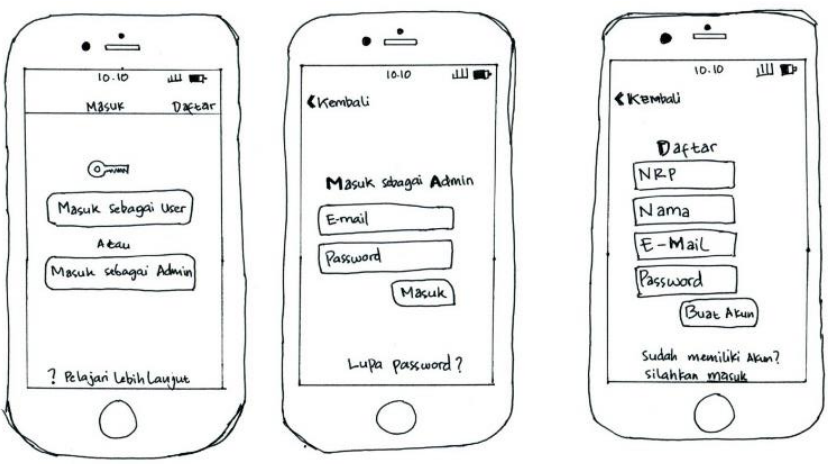

Gambar 9. Sketsa Halaman login pada Admin

Sedangkan pada user, terdapat pula halaman login yang hampir mirip dengan halaman login admin. Apabila user memilih tombol masuk baik sebagai user maupun admin, maka ia akan diarahkan untuk login dan harus memasukkan alamat email dan password. Sedangkan jika user memilih pelajari lebih lanjut, maka akan ditampilkan halaman bantuan. Berikut gambar dari halaman beranda:
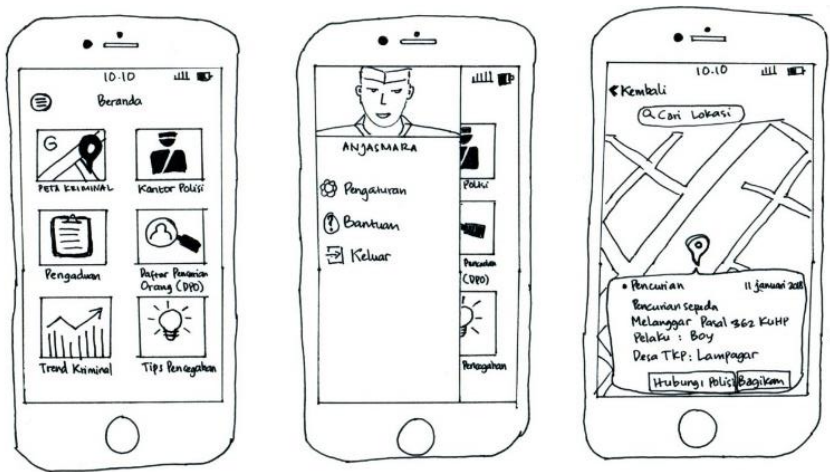

Gambar 10. Sketsa Halaman Beranda dan peta kriminal

Setelah user berhasil login, maka selanjutnya akan diarahkan ke halaman beranda. Pada halaman ini terdapat beberapa menu yang dapat diakses, seperti peta criminal, kantor polisi, pengaduan, Daftar Pencarian Orang (DPO), trend criminal, serta tips pencegahan. Selain itu juga tersedia menu pengaturan disebelah kiri. Berikut gambar dari halaman Peta Kriminal pada admin:
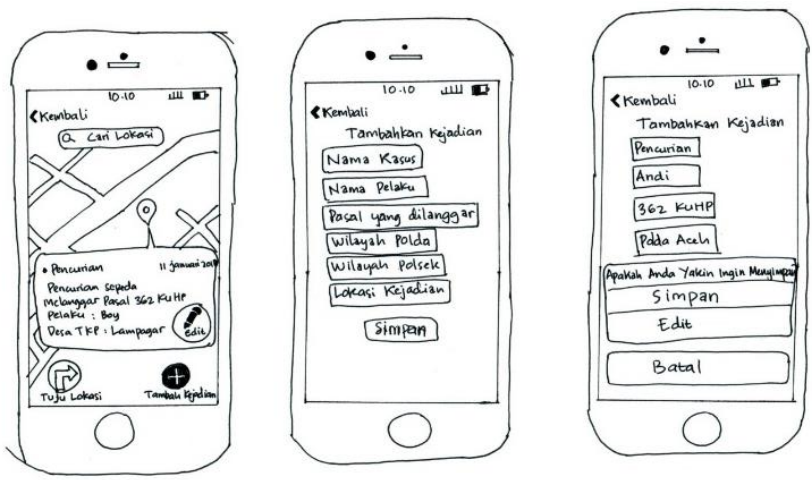

Gambar 11. Sketsa Halaman Peta Kriminal pada admin

Saat user memilih menu peta criminal, maka user akan diarahkan ke tampilan peta yang menampilkan lokasi kejadian criminal. Jika user mengklik di lokasi, maka akan muncul informasi kejadian. Kemudian admin juga dapat membuat kejadian baru serta menambahkan informasi didalamnya. Setelah membuat kejadian, lalu admin dapat menyimpan kejadian tersebut. Selanjutnya juga ada halaman kantor polisi seperti pada gambar berikut:
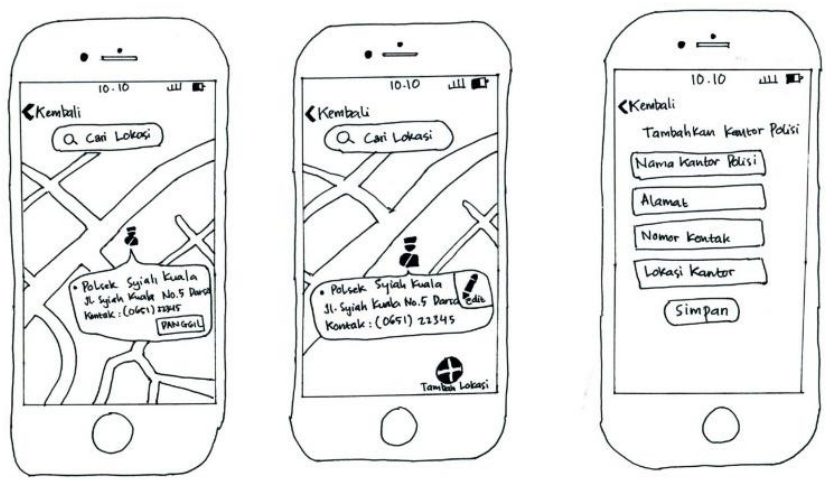

Gambar 12. Sketsa Halaman Kantor Polisi pada user dan halaman edit kantor polisi

Saat user memilih menu kantor polisi, maka user akan diarahkan ke tampilan peta yang menampilkan lokasi kantor yang terdekat dengan user. Jika user mengklik di lokasi, maka akan muncul informasi kantor. Selain itu, user juga dapat mengedit dan menambahkan kantor polisi. Setelah itu, user dapat menyimpan kantor polisi tersebut. Kemudian juga ada halaman pengaduan seperti pada gambar berikut:
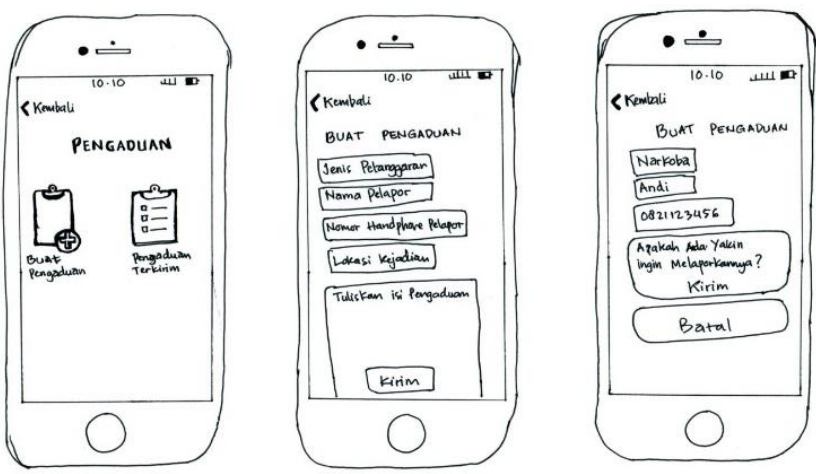

Gambar 13. Sketsa Halaman buat pengaduan pada user

Pada bagian ini terdapat halaman pengaduan yang dapat digunakan oleh user untuk membuat pengaduan kepada polisi. Saat user memilih menu pengaduan, maka user akan diarahkan ke tampilan dua submenu yaitu pengaduan baru dan riwayat pengaduan. Jika user mengklik pengaduan baru, maka akan muncul formulir yang dapat diisi dan disimpan. Sedangkan jika user mengklik riyawat pengaduan, maka akan muncul riwayat dari pengaduan yang telah dibuat: 

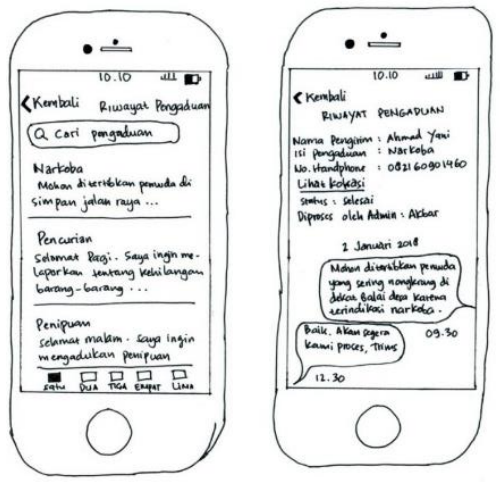

Gambar 14. Sketsa Halaman pengaduan terkirim pada user Selain itu, user juga dapat menambahkan komentar pada pengaduan yang telah dibuat. Dengan demikian, dapat lihat kemajuan dari proses pengaduan tersebut. Kemudian juga terdapat halaman Daftar Pencarian Orang (DPO) yang ditampilkan seperti berikut:
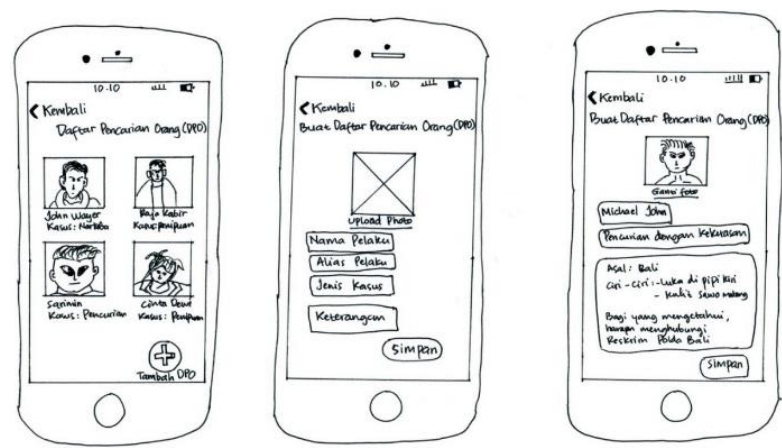

Gambar 15. Sketsa Halaman Buat Daftar Pencarian Orang (DPO)
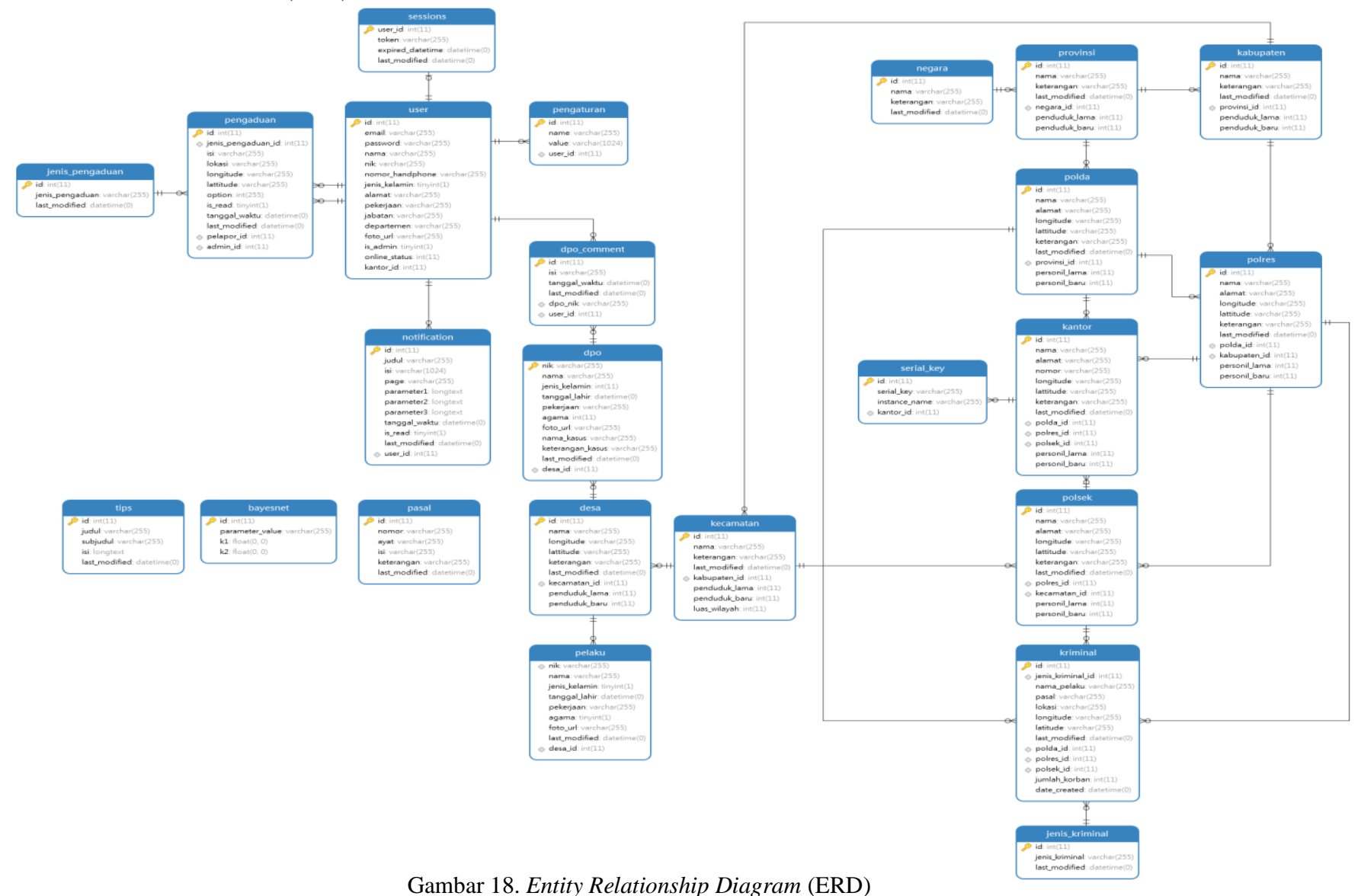

Pada fitur Daftar Pencarian Orang (DPO), user akan diarahkan ke tampilan foto-foto dari DPO yang telah diposting oleh admin. Saat user mengklik pada salah satu foto DPO, maka user akan diarahkan pada tampilan informasi detail dari DPO tersebut. Selain itu, juga terdapat fitur buat daftar pencarian orang (DPO) pada admin:
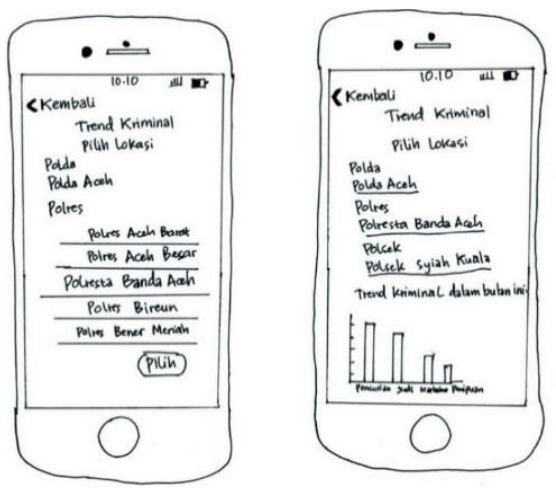

Gambar 16. Sketsa Halaman Trend Kriminal

Pada fitur trend criminal, user dan admin akan diarahkan ke tampilan daftar lokasi yang dipilih mulai dari tingkat Polda, Polres, hingga Polsek. Setelah memilih lokasi, selanjutnya user dan admin mengklik tombol tampilkan dan sistem akan menampilkan trend criminal. 
Selanjutnya juga terdapat halaman tips pencegahan seperti pada gambar berikut:
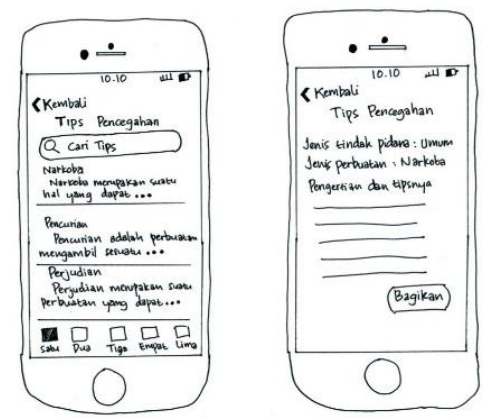

Gambar 17. Sketsa Halaman Tips Pencegahan pada user Pada halaman tips pencegahan, terdapat tampilan daftar tips yang dapat diklik oleh user untuk menampilkan pencegahan. Adapun tips tersebut juga dapat dibuat oleh admin dan user hanya dapat melihatnya saja tanpa bisa merubahnya.

\section{Entity Relationship Diagram (ERD)}

Setelah didapatkan rancangan pada aplikasi, tahap selanjutnya dimodelkan rancangan pada database aplikasi sehingga aplikasi berhasil dijalankan. Oleh karena itu, maka digunakan teknik pemodelan yang disebut dengan Entity Relationship Diagram (ERD) yang sering digunakan untuk mendesain relasi dari database di lapangan. Pemodelan ERD mengilustrasikan bagaimana entitas seperti orang, objek, atau konsep saling berhubungan dalam sistem. Pada sistem pemetaan kriminal, terdapat beberapa komponen dari ERD seperti entitas, relationship, atribut, dan kardinalitas yang dapat dilihat pada Gambar 18 .

\section{KESIMPULAN}

Penelitian ini berhasil mengetahui kebutuhan user untuk pemetaan kriminal. Selain itu, penelitian ini berhasil merancang aplikasi peristiwa kriminal menggunakan pendekatan Contextual Design yang sesuai dengan kebutuhan user. Kemudian desain antarmuka (user interface) pada aplikasi peristiwa kriminal telah berhasil dibuat melalui wawancara kontekstual, interpretasi, konsolidasi data, visioning, storyboarding, user environment design, dan prototyping. Untuk penelitian lanjutan, akan dilakukan implementasi rancangan beserta pengujian usability testing pada aplikasi.

\section{REFERENSI}

[1] Yusrizal, "Perancangan Dan Implementasi Aplikasi Catatan Kriminal di Polsek Krueng Barona Jaya", Laporan Tugas Akhir, Universitas Syiah Kuala, Banda Aceh, Indonesia, 2014.

[2] Yusrizal, "Perancangan Dan Implementasi Pemetaan Daerah Kerawanan Gangguan Ketertiban Masyarakat (Guantibmas) Berbasis Google Earth Pada Wilayah Hukum Polsek Krueng Barona Jaya," Laporan Kerja Praktek, Universitas Syiah Kuala, Banda Aceh, Indonesia, 2013.

[3] Irjen Arief Sulistiyanto, "Polri: Jumlah Personel Belum Ideal, 1 Polisi Jaga 750 Warga," detik.com, para. 21, Feb 2017.
[4] W. Jakkhupan and P. Klaypaksee, "A web-based kriminal record system using mobile device: A case study of Hat Yai municipality," in Proc. of the 2014 Asia Pacific Conference on Wireless and Mobile, 19-21 May 2014, Bali, Indonesia.

[5] M. Lnenicka, J. Hovad, J. Komarkova and M. Pasler, "A proposal of web data mining application for mapping crime areas in the Czech Republic," in Proc. of the 2015 10th International Joint Conference on Software Technologies (ICSOFT), 20-22 July 2015, Colmar, France.

[6] Guiyun Zhou, Jiayuan Lin and Wenfeng Zheng, "A webbased geographical information system for crime mapping and decision support," in Proc. of the 2012 International Conference on Computational Problem-Solving (ICCP), 1921 October 2012, Leshan, China.

[7] D. V. Rohini and P. Isakki, "Crime analysis and mapping through online newspapers: A survey," in Proc. of the 2016 International Conference on Computing Technologies and Intelligent Data Engineering (ICCTIDE'16), 7-9 January 2016, Kovilpatti, India.

[8] X. Li and M. Juhola, "Crime and Its Social Context: Analysis Using the Self-Organizing Map," in Proc. of the 2013 European Intelligence and Security Informatics Conference, 12-14 August 2013, Uppsala, Sweden.

[9] E. Johansson, C. Gåhlin and A. Borg, "Crime Hotspots: An Evaluation of the KDE Spatial Mapping Technique," in Proc. of the 2015 European Intelligence and Security Informatics Conference, 7-9 September 2015, Manchester, UK.

[10] X. Zhang, Z. Hu, R. Li and Z. Zheng, "Detecting and mapping crime hot spots based on improved attribute oriented induce clustering," in Proc. of the 2010 18th International Conference on Geoinformatics, 18-20 June 2010, Beijing, China.

[11] S. Khalid, Jiechen Wang, M. Shakeel and Xia Nan, "Spatiotemporal Analysis of the Street Crime hotspots in faisalabad city of Pakistan," in Proc. of the 2015 23rd International Conference on Geoinformatics, 19-21 June 2015, Wuhan, China.

[12] A. Muyanja, P. I. Musasizi, C. Nassimbwa, S. S. TickodriTogboa, E. K. Kayihura and A. Ngabirano, "Requirements engineering for the uganda police force crime records management system," in Proc. of the 2013 21st IEEE International Requirements Engineering Conference (RE), 15-19 July 2013, Rio de Janeiro, Brazil.

[13] A. S. Kumar and R. K. Gopal, "Data mining based crime investigation systems: Taxonomy and relevance," in Proc. of the 2015 Global Conference on Communication Technologies (GCCT), 23-24 April 2015, Thuckalay, India.

[14] C. Oduor, F. Acosta and E. Makhanu., The adoption of mobile technology as a tool for situational crime prevention in Kenya, IST-Africa Conference Proceedings, May 7-9, 2014, Le Meridien Ile Maurice, Mauritius, IEEE, 2014.

[15] Hermawan, Alvin Sofiyan, Tacbir Hendro Pudjiantoro, and Irma Santikarama. "PEMBANGUNAN SISTEM INFORMASI KRIMINALITAS DI KEPOLISIAN RESORT CIMAHI." Prosiding SNST Fakultas Teknik 1.1, 18 July 2018, Semarang, Indonesia. Universitas Wahid Hasyim Semarang, 2018.

[16] Lubis, Hendarman, Ratna Salkiawati, and Muhamad Adilla Dhiya Ulhaq. "Sistem Informasi Kriminalitas Berbasis 
Android." Jurnal Algoritma vol. 15, no. 2 pp. 48-60, November 2018.

[17] V. Furtado, C. Caminha, L. Ayres and H. Santos, "Open Government and Citizen Participation in Law Enforcement via Crowd Mapping," in IEEE Intelligent Systems, vol. 27, no. 4, pp. 63-69, July-Aug. 2012.

[18] Chainey, Spencer, and Jerry Ratcliffe. GIS and crime mapping. West Sussex: John Wiley \& Sons, 2013.

[19] Holtzblatt, Karen, and Hugh Beyer. "Contextual Design: Evolved." Synthesis Lectures on Human-Centered Informatics 7.4. California: Morgan \& Claypool, 2014.

\section{BIOGRAFI PENULIS}

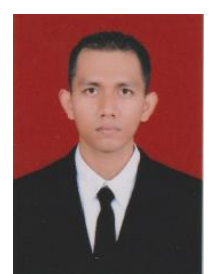

Yusrizal

Menyelesaikan pendidikan sarjana di Jurusan Teknik Elektro dan Komputer Universitas Syiah Kuala. Merupakan salah satu peneliti bidang komputer dengan minat Interaksi Manusia dan Komputer (Human-Computer Interaction) di Jurusan Teknik Elektro dan Komputer, Fakultas Teknik, Universitas Syiah Kuala. 